\title{
Manifestasi Kearifan Lokal sebagai Akar Nasionalisme Pancasila pada Dialog Lintas Agama di Kaloran, Temanggung
}

\author{
Oleh: Suranto \\ Dosen Sekolah Tinggi Agama Buddha Syailendra \\ suranto.syailendra@gmail.com
}

\begin{abstract}
The purpose of this article is to provide a description of the analysis of local wisdom in the community as the root of Pancasila in interfaith dialogue. The Indonesian nation was built on the basis of diversity of cultures, religions, races, and ethnicities. The foundation is inseparable from the social politic that initiated the building of the Indonesian nation. Without the diversity above, the Indonesian nation is not constructed as the Unitary State of the Republic of Indonesia (NKRI). Local wisdom in every corner of the Indonesian nation has become the root of Pancasila. Through this sociological approach, it can be seen that the local wisdom that exist in the Kaloran, Temanggung becomes the root cause of the ideology of the Pancasila as the basis for living its relationship with interfaith dialogue. Through activities from local wisdom such as sadranan and culture that exist in the Kaloran, Temanggung community becomes a medium for interfaith dialogue which constructively as a collective awareness of that diversity. Local wisdom that exist in Kaloran is a mean of community cohesiveness, an instrument of dialogue with heart, and a public space for interfaith dialogue.
\end{abstract}

Keywords: Local wisdom, Pancasila, Interfaith dialogue, and Religious diversity. 


\begin{abstract}
Abstrak
Tujuan dari artikel ini akan memberikan deskripsi analisis dari kearifan lokal yang ada di masyarakat sebagai akar nasionalisme pancasila pada dialog lintas agama. Bangsa Indonesia dibangun atas dasar keragaman budaya, agama, ras, suku, dan etnisitas yang majemuk. Pondasi tersebut tidak lepas dari sosial politik yang menggagas bangunan bangsa Indonesia. Tanpa adanya keragaman di atas, bangsa Indonesia tidak terkonstruksi sebagai Negara Kesatuan Republik Indonesia. Kearifan lokal yang ada di setiap sudut bangsa Indonesia telah menjadi akar dari nasionalisme Pancasila. Melalui pendekatan sosiologi ini dapat diketahui bahwa kearifan lokal yang ada di masyarakat Kaloran, Temanggung menjadi akar yang menompang ideology pancasila sebagai landasan hidup relasinya dengan dialog lintas agama. Melalui kegiatan dari kearifan lokal seperti sadranan dan budaya yang ada di masyarakat Kaloran, Temanggung menjadi sarana dalam dialog lintas agama yang secara konstruktif menjadi kesadaran kolektif atas keberagaman tersebut. Kearifan lokal yanga ada di Kaloran menjadi sarana kohesifitas masyarakat, instrument dialog dengan hati, dan ruang public pada dialog lintas agama.
\end{abstract}

Keywords: Kearifan Lokal, Nasionalisme Pancasila, Dialog, dan Lintas Agama

\title{
Pengantar
}

Kekerasan atas nama agama yang terjadi di Indonesia masih menjadi tantangan yang cukup krusial di masa sekarang. Rentetan peristiwa bom bunuh diri atas nama agama menjadi bukti tantangan kehidupan umat beragama di Indonesia. Berawal dari bom Bali pada tahun 2002 yang kemudian banyak bermunculan kasus serupa baik di Jakarta maupun Surabaya. Begitu juga, konflik atas sentiment keagamaan yang terjadi di Maluku antara Kristen dan Islam masih menjadi bukti tantangan kehidupan beragama di Indonesia (Al Qurtuby, 2016; Lattu, 2012). Meskipun demikian, Bangsa Indonesia memiliki kemampuan dalam mengatasi konflik atas sentiment keagamaan tersebut karena konflik tidak berkepanjangan. Kemampuan tersebut tampak dari berbagai bentuk dan reaksi yang muncul diberbagai level masyarakat maupun gerakan dari pemerintah Indonesia dalam menciptakan suasana keharmonian lintas agama. Kemampuan dalam level masyarakat ini dapat terlihat dari berbagai aktivitas masyarakat yang melibatkan berbagai unsur lintas agama. Seperti pembangunan rumah ibadah yang secara gotong royong dilakukan oleh masyarakat yang lintas agama, kegiatan sadranan sebagai 
media dialog lintas agama, maupun kegiatan kearifan lokal yang menjadi media bersama untuk merajut kehidupan lintas agama. Selain itu, secara legal pemerintah telah membentuk Forum Kerukunan Umat Beragama (FKUB) yang menjadi media kehidupan lintas agama. Melalui hal di atas menjadi bagian dalam membangun kerukunan kehidupan lintas agama di Indonesia secara umum.

Meskipun demikian, yang menjadi pertanyaan mengapa kemampuan tersebut dimiliki oleh masyarakat dalam membangun dialog lintas agama pada aras lokal sebagai akar nasionalisme Pancasila? Dari berbagai pertanyaan tersebut mengarahkan penulis untuk melihat lebih jauh relasi kehidupan lintas agama dalam masyarakat khususnya di wilayah Kaloran, Temanggung. Wilayah Kaloran, Temanggung dengan populasi umat beragama yang berimbang baik komunitas Kristen, Islam, maupun Buddha menjadi daya tarik tersendiri bagi penulis ${ }^{1}$. Relasi kehidupan lintas agama di Kaloran, Temanggung dapat menjadi bagian dari potret kehidupan lintas agama yang dinamis. Dengan kata lain, bukan berarti tidak ada konflik lintas agama, tetapi mempunyai kemampuan dalam mendialogkan diri dalam mewujudkan kerukunan lintas agama. Melalui pendekatan ini terutama pada bahasan mitos yang menjadi instrumen kohesifitas masyarakat, bahasa sebagai instrumen dialog dengan hati, dan kearifan lokal sebagai ruang publik ini akan menjadi pokok pembahasan dalam artikel ini. Oleh karena itu, dalam artikel ini akan melihat analisis akar nasionalisme Pancasila ini menjadi immune masyarakat Kaloran, Temanggung dalam menjaga relasinya dengan masyarakat lintas agama yang harmonis. Berdasarkan argumen di atas, maka argumentasi utama dalam artikel ini akan menunjukkan manifestasi budaya lokal sebagai akar nasionalisme Pancasila di masyarakat Kaloran menjadi landasan dalam menjalin hubungan kehidupan dialog lintas agama.

\section{Deskripsi Kehidupan Sosial Keagamaan di Kaloran, Temanggung}

Wilayah Kaloran, Temanggung mempunyai komunitas umat beragama yang cukup beragam. Secara populasi dapat dipetakan basis-basis komunitas tersebut. Sebagai contoh di wilayah Timur lebih didominasi umat Buddha, kemudian di wilayah tengah lebih didominasi komunitas umat Kristen, dan wilayah barat di dominasi umat Islam. Meskipun demikian, setiap dusun atau desa terdapat komunitas umat Islam,

\footnotetext{
${ }^{1}$ Menurut Data statistik Kabupaten Temanggung khususnya Kecamatan Kaloran pada tahun 2016 Jumlah umat Islam 36. 726, Kristen Protestan: 903, Katolik: 756, Buddha: 7.824. Diakses pada 1 November 2018 lewat portal Badan Pusat Statistik Kabupaten Temanggung (www.temanggungkab.bps.go.id)
} 
Kristen, maupun Buddha. Sebagai contoh, di Dusun Porot, Desa Getas, warganya ada yang memeluk agama Islam, Kristen, maupun Buddha. Begitu juga dengan desa yang lain, setiap desa memiliki warga masyarakat yang memeluk agama yang beragam. Kondisi plural ini yang menjadikan proses dialog lintas agama selalu terjadi dalam masyarakat Kaloran, Temanggung.

Berbagai aktifitas sosial keagamaan yang ada di Kaloran, Temanggung menjadi media dalam merajut relasi kehidupan sosial keagamaan masyarakat. Melalui prinsip gotong royong, pembangunan tempat ibadah sering dilakukan atas kerja sama umat lintas agama, baik pembangunan masjid, wihara, maupun gereja. Keterlibatan dalam pembangunan tempat ibadah ini menjadi aktifitas sosial keagamaan masyarakat di Kaloran, Temanggung. Selain itu, pembangunan rumah warga dan bahkan pembuatan lubang untuk kuburan warga sering dilakukan atas dasar kegotongroyongan dari komunitas lintas agama. Tidak hanya kondisi itu saja yang melibatkan kerja sama lintas agama, dalam kondisi mulai dari proses kelahiran yang ada tradisi selamatan, perkawinan, dan akhirnya masalah kematian tidak terlepas dari kerja sama lintas agama yang ada di Kaloran, Temanggung.

Begitu juga, dalam membangun relasi sosial keagamaan masyarakat Kaloran, Temanggung melalui keterlibatan tokoh lintas agama dalam memperingati perayaan hari besar keagamaan. Sebagai contoh, ketika umat Kristen sedang merayakan Natal, undangan perayaan tersebut sampai pada tokoh lintas agama baik Islam, maupun Buddha. Begitu juga, pada perayaan Waisak oleh umat Buddha, juga dihadiri oleh tokoh umat Kriten maupun Islam. Tidak terlewatkan, ketika Idul fitri, umat Kristen dan Buddha juga melakukan kunjungan ke rumah umat Islam sebagai bentuk keterlibatan sosial keagamaan masyarakat.

Selain itu, terdapat berbagai bentuk budaya di Kaloran menjadi media beraktifitas lintas agama sehingga tercipta kehidupan sosial keagamaan yang baik. Melalui budaya Sadranan (selamatan yang dilakukan di Kuburan dan sungai) menjadi aktifitas sosial keagamaan bersama di masyarakat Kaloran yang tampak dari kegiatan doa lintas agama dalam sadranan tersebut. Kemudian, melalui kesenian yang berupa kuda kepang, sorengan, ketoprak, seni wayang, prajuritan, topeng ireng, dan berbagai seni di Kaloran menjadi media ruang bersama dalam merajut kehidupan lintas agama. Sebagai contohnya para seniman tersebut terdiri dari berbagai unsur lintas agama baik Islam, Kristen, dan Buddha. 
Berbagai aktiftas sosial keagamaan di atas menjadi potret kehidupan masyarakat Kaloran, Temanggung dalam menjaga relasi sosialnya. Meskipun demikian, bukan berarti tidak pernah ada konflik lintas agama di masyarakat Kaloran. Justru melalui konflik tersebut menjadi uji coba kematangan dalam menjalin relasi keagamaan di masyarakat Kaloran. Konflik pernah terjadi di masyarakat Kaloran, Temanggung. Sebagai contoh pada tahun 2008, terjadi konflik antar komunitas Islam dengan Buddha di desa Kalimanggis, namun dapat diselesaikan dengan apik. Kemudian pada tahun 2010, pernah terjadi konflik antar umat Kristen dengan Buddha di Batursari, Tleter, Kaloran. Hal tersebut, dipicu atas kesalahpahaman. Kemudian pada tahun 2016, juga terjadi insiden yang menyeruak di komunitas Muslim dan Buddha di dusun Lamuk, Kaloran yang dapat diredam dengan baik sehingga tidak menimbulkan konflik yang berkepanjangan. Melalui konflik ini, sejatinya menjadi momentum bersama dalam masyarakat Kaloran untuk menjaga dan membangun imunitas masyarakat dalam menghadapi konflik antar relasi umat beragama.

\section{Relasi antar Umat Beragama dan Tantangannya}

Relasi antar umat beragama menjadi pintu untuk mendialogkan diri dalam tujuannya membangun keharmonian masyarakat. Seperti yang disampaikan oleh Izak Lattu bahwa interfaith or interreligious dialogue is the gate to enter the realm of religious knowledge and vehicle for bringing religious followers to peaceful interaction (Izak, 2018: 2). Melalui dialog relasi umat beragama ini dapat membangun kesadaran bersama atas perbedaan agama yang pada akhirnya menumbuhkan keterbukaan dan kesadaran atas dasar perbedaan agama di masyarakat. Relasi antar umat beragama ini tidak hanya mengaungkan persamaannya saja, melainkan menjadi ruang belajar bersama atas perbendaan yang ada pada komunitas umat beragama (Swidler, 2013: 15). Relasi beragama yang ada di masyarakat Kaloran, Temanggung tidak terlepas dari dialog antar umat beragama yang bermakna. Kebermaknaan yang berkembang tersebut, tampak dari aktifitas dan ruang lingkup dialog yang terjadi pada relasi keseharian mereka dalam menjalin kehidupan bermasyarakat. Dialog yang menjadi keseharian dalam bermasyarakat menumbuhkan makna dialog ini pada tataran yang mendalam dan keluar dari sekat-sekat tekstual.

Penekanan dialog yang tidak hanya tekstual namun mendasarkan pada tataran kontekstual ini menjadi relasi antar umat beragama yang bermakna. Hal ini juga dikemukakan oleh Siddiqui bahwa the aim of interreligious dialogue is to move toward mutual understanding and action (Siddiqui, 1997: 52). Begitu juga dalam mengembang relasi yang bermakna ini dapat dijembatani dengan adanya budaya 
untuk saling memahami. Kontekstualisasi makna keberagamaan yang saling memahami menjadi nilai penting dalam membangun relasi beragama. Hal ini juga ditekankan oleh Paul Knitter (dalam Izak, 2018: 2) bahwa dialogue based on cultural understanding is the key for dialogue of life. Tanpa adanya pemahaman kultural yang baik akan mengalami tantangan dalam berdialog.

Tantangan yang muncul pada relasi antar umat beragama ini pada tataran menempatkan dialog antar umat beragama sebagai bagian dari relasi keseharian yang menjadi kehidupan lebih bermakna. Bukan pada perdebatan tekstual yang kadang kontroversi muncul hanya pada aras kulit luar dari agama, bukan pada makna agama itu sendiri. Penekanan pada kondisi ini juga ditawarkan oleh Swidler (2014: 377-378) bahwa the dialogue of head, hands, and hearts to curve the holistic idea of interreligious dialogue; dialogue of head is meant openness and ability to learn from other religions; dialogue of hands is togetherness in working with others; and dialogue of hearts is religious believers to open the room for appreciating and accepting the beauty of other traditions and teachings. Dialog yang totalitas ini dapat menjadikan relasi antar umat beragama lebih bermakna. Meskipun demikian, tawaran dialog yang sepenuh hati ini menjadi tawaran solusi dan juga menjadi tantangan pada relasi antar umat beragama yang belum berjalan dengan kebermaknaan. Dalam masyarakat plural ini dialog antar umat beragama menjadikan sumber pemahaman atas perbedaan nilai dan tradisi keagamaan dalam menciptakan mutualisme pemahaman (Madjid, 1999: 63).

Relasi umat beragama yang terjadi di masyarakat Kaloran ini tidak terlepas dari tawaran dialog tersebut. Meskipun demikian, yang perlu dilihat lebih dalam mengenai bagaimana relasi-relasi umat beragama tersebut berdialog dengan menggunakan kearifan lokal sebagai akar nasionalisme pancasila sampai pada tataran kontekstualisasi kehidupan beragama baik berdasarkan mitologi, bahasa, komunitas, dan budaya sebagai ruang publik pada masyarakat Kaloran.

\section{Kearifan Lokal Akar Nasionalime Pancasila pada Dialog Lintas Agama}

Diskursus nasionalime Pancasila bukan berarti fokus pada masalah-masalah nasional yang menjadi objek pembahasan, melainkan bagaimana secara sosiologi, mitologi, idelogi, bahasa, dan budaya relasinya munculnya nasionalisme Pancasila. Melalui diskursus ini sebenarnya dapat membantu penulis dalam memahami relasi dialog umat beragama dengan pendekatan diskursus kearifan lokal, nasionalisme Pancasila, dan relasi agama sehingga memberikan relevansi dalam menciptakan 
kehidupan umat beragama yang baik. Diskursus ini menjadi perspektif dalam memahami dialog lintas agama yang terjadi di masyarakat Kaloran, Temanggung. Diskursus nasionalisme Pancasila tidak pernah akan tercipta tanpa adanya kearifan lokal yang menjadi pondasi dari realitas sosial bangsa Indonesia. Bangsa Indonesia melihat realitas keberagamaan menjadi fakta yang unik dan indah. Keberagamaan menjadi sumber kekayaan bangsa yang telah terwadahi dalam Pancasila sebagai asas dan filosofi bangsa. Narasi ini tidak terlepas dari perkembangannya secara sosio historis bangsa ini. Konsep keberagamaan ini adalah hasil dinamisasi sosial historis bangsa terhadap keragamaan budaya, yang pada akhirnya menjadi bukti pemenuhan kebutuhan utama setiap manusia bangsa Indonesia ${ }^{2}$. Berangkat dari keragama budaya ini yang menjadi akar kosep keberagaman bangsa Indonesia yang unik dan transformatif.

Trasnformasi budaya yang berawal dari mitologi, idiologi, komunitas, dan budaya itu sendiri menjadi gagasan utama dalam membangun bangsa Indonesia relasinya dengan keberagaman agama. Pendekatan mitologi ini merupakan bagian penting dalam suatu masyarakat. Mitologi meskipun konstruksi masyarakat, pada tataran tertentu masih dibutuhkan dalam masyarakat itu sendiri ${ }^{3}$. Begitu juga Karen Amstrong (2015) menjelaskan mengenai mitologi yang sangat erat relasinya dengan manusia dalam memahami fenomena. Pada diskursus ini, masyarakat di Kaloran memiliki dasar mitologi dalam menjalin kehidupan bermasyarakat termasuk relasinya dengan antar umat beragama. Dasar mitologi tersebut bahwa dalam satu komunitas masyarakat mempunyai leluhur yang sama. Sebagai contoh, di dusun Depok, dusun Kemiri, dusun Mruwah mempunyai relasi leluhur yang sangat dekat sehingga dalam berbagai komunikasi dapat terbangun atas dasar keyakinan atas kelahiran dari leluhur yang sama. Melalui kesadaran pada mitologi ini, relasi dialog lintas agama dapat terbangun dengan baik.

Kemudian pembahasan mengenai idiologi budaya bahwa kesadaran atas keragaman tradisi dan kemajemukan menjadi bagian terpenting dalam membangun relasi dialog lintas agama. Kesadaran atas hal ini sering dianalogikan pada endog sak petarangan bedo-bedo (telur satu sarang kalau menetas melahirkan ayam yang mempunyai banyak warna dan keragaman). Analogi ini menjadi pemikiran masyarakat di Kaloran pada khususnya dan Jawa pada umumnya. Melalui

\footnotetext{
2 John A. Titaley. 2013. Religiositas Alinea Tiga: Pluralisme, Nasionalisme, dan Transformasi Agamaagama. Salatiga: Satya Wacana University Press. Hal. 153

${ }^{3}$ Penjelasan dari Yusak B. Setyawan mengenai Mitos pada kelas Kitab Keagamaan dan Masyarakat pada hari Selasa, 18 September 2018.
} 
pemahaman ini dapat dipahami oleh masyarakat atas dasar perbedaan karakter, termasuk agama.

Kemudian mengenai bahasa sebagai media memberikan makna menjadi bangunan yang penting dalam relasi antar umat beragama. Dalam masyarakat Kaloran terutama dalam memaknai Tuhan dengan berbagai ungkapan bahasa yang dapat dipahami dalam masyarakat tersebut. Berbagai nama dalam menyebutkan Tuhan dalam dialog umat beragama di Kaloran. Ada yang menyebut Tuhan dengan Gusti Allah, Gusti Pangeran, Gusti Kang Maha Agung, Gusti Kang Murbei, dan juga dengan bahasa keagamaan yang terdapat pada kitab agama masing-masing tidak menjadikan kendala dalam membangun relasinya dengan antar umat beragama. Sepertih halnya John Hick menyampaikan bahwa God has many names (1980). Ungkapan bahasa ini sangat relatif, meskipun demikian masyarakat memahami apa makna yang disampaikan meskipun dengan bahasa dan penyebutan yang beragam. Seperti halnya Sallie McFague (1982) yang menjelaskan mengenai model Tuhan dalam bahasa agama memberikan ruang dialog atas keberadaan transenden dengan metafora agama.

Selain itu, keberadaan budaya dalam komunitas menjadi hal penting dalam relasinya bahasa sebagai budaya sebagai instrumen diskursus mengenai relasi dialog lintas agama. Seperti yang menjadi diskusi mengenai bahasa sebagai bagian penting dalam masyarakat menjelaskan bahwa budaya is performance of language, and language is a part of the inner fabric of society, culture, ideology, and religion ${ }^{4}$. Sedangkan budaya tersebut tidak terlepas dari nilai yang ada didalamnya. Begitu juga dengan masyarakat antar umat beragama di Kaloran memanfaatkan budaya dan komunitas sebagai bagian dari ruang dialog antar umat beragama di ruang publik. Sebagai contoh melalui kegiatan sadranan dan budaya kesenian. Seperti halnya ruang publik yang dikemukakan oleh Jurgen Hubermas (dalam Turner, 1998 560) mengenai agama dan ruang publik. Meskipun demikian, ruang publik yang disampaikan di masyarakt Kaloran tidak dilakukan di café-café, melainkan ruang publik dapat dilakukan di kuburan atau lapangan berkesenian.

Melalui frame dan terma-terma ini kearifan lokal sebagai akar nasionalisme pancasila menjadi relevansi pada dialog lintas agama di masyarakat Kaloran, Temanggung. Preposisi dalam kearifan lokal dan nasionalisme pancasila dapat

\footnotetext{
${ }^{4}$ Materi kuliah Kitab Keagamaan dan Masyarakat oleh Yusak B. Setyawan Ph. D. yang dijelaskan pada hari Selasa, 23 Oktober 2018.
} 
digunakan dalam menganalisis permasalahan yang ada kaitannya dengan dialog lintas agama.

\section{Relevansi Kearifan Lokal sebagai Kohesifitas, Instrumen, dan Ruang Publik}

Melalui pembahasan dalam artikel ini akan lebih fokus pada mitos sebagai dasar kohesifitas antar umat beragama di Kaloran, Temanggung, kemudian unsur bahasa ini akan menjadi instrumen dialog dengan hati, dan Budaya kearifan lokal menjadi ruang publik masyarakat Kaloran, dalam menjaga kerukunan umat beragama. Hal tersebut menjadi manifestasi kearifan lokal sebagai akar nasionalisme pancasila relasinya dengan dialog lintas agama di bangsa Indonesia.

\section{a. Kohesifitas Masyarakat atas Dasar Mitos}

Masyarakat Kaloran mempunyai kompleksitas relasi umat beragama yang cukup unik. Dalam satu keluarga telah lahir realitas multi agama yang menjadikan wajah keluarga tersebut sebagai akar dari Pancasila dasar negara. Tidak asing lagi di setiap keluarga anggota keluarga tersebut terdiri dari berbagai macam agama yang dipeluk oleh masing-masing indvidu dari satu keluarga. Seperti yang disampaikan oleh Suhadi mengenai beliau berasal dari keluarga yang beragama Pancasila (Suhadi, 2014: 193). Dalam masyarakat di Kaloran banyak ditemui realitas keluarga tersebut. Meskipun demikian, ada pemahaman yang menjadi mitos bersama dalam membangun keharmonian relasi keluarga dan masyarakat yang dibangun di atas ego sektorial. Kesadaran atas terlahir dari leluhur yang sama tersebut menjadi mitos bersama sehingga tidak etis ketika terjadi konflik atas perbedaan agama baik dalam ranah keluarga maupun dalam komunitas.

Sebagai contoh, dalam kasus kekerasan yang pernah terjadi pada tahun 2008 di Kalimanggis pada komunitas Islam dan Buddhis tersebut dapat diselesaikan dengan dialog atas dasar bahwa mereka terlahir dari nenek moyang leluhur yang sama sehingga mereka menyadari atas keterikatan keluarga lebih penting daripada konflik yang justru merusak relasi kehidupan sosial masyarakat. Meskipun, realitasnya dalam komunitas masyarakat tersebut tidak hanya berasal dari warga asli, tetapi banyak pendatang yang tinggal di daerah tersebut. Tetapi keyakinan atas dasar kesamaan nenek moyang leluhur ini lebih kuat daripada hanya pada rasionalitas masyarakat semata. Tidak berhenti pada tataran ini saja dalam relasinya sebagai bagian dari asal usul leluhur yang sama, tetapi sampai pada tataran keyakinan bahwa tidak akan diizinkannya hubungan pernikahan yang masih memiliki relasi nenek moyang yang dengan antara dusun yang satu dengan yang lain. 
Relasi pernikahan yang tidak dapat direalisasikan antara anggota masyarakat ini terjadi pada masyarakat Dusun Depok dengan Dusun Mruwah. Leluhur yang ada di Dusun Depok yaitu Eyang Purnomo yang menjadi kakaknya Eyang Datoko yang menjadi leluhur di Dusun Mruwah. Keyakinan masyarakat ini bahwa leluhur mereka masih mempunyai relasi yang sangat dekat sehingga apabila terjadi pernikahan maka akan mengalami hal yang tidak baik. Kejadian pelanggaran tersebut dialami oleh keluarga Ibu Rubiah yang kemudian mengalami perceraian. Perceraian ini yang kemudian direlasikan dengan adanya pesan leluhur bahwa dengan leluhur yang sama tidak dapat menjalani pernikahan. Begitu kuatnya, keyakinan pada kesamaan leluhur tersebut menjadi nilai yang kuat dalam relasinya antar umat beragama. Selain itu, masyarakat Kaloran mempunyai kesadaran yang kemudian dimitoskan bahwa realitas perbedaan tersebut sudah menjadi kodratnya dari yang transenden.

Sudah menjadi kewajaran bahwa manusia tersebut terlahir dengan berbagai karakter termasuk dengan keyakinan. Kesadaran ini tumbuh seiring dengan realitas dengan analogi yang dibangun atas konstruksi masyarakat Kaloran dengan analogi telur dalam satu sarang akan menghasilkan ayam yang memiliki bulu, warna, dan karakter yang sangat bervariasi. Analogi ini yang menjadi prinsip kehidupan bersama dalam masyarakat Kaloran. Termasuk perbedaan agama tidak menjadi kendala dalam membangun kehidupan yang bermakna. Selain hal tersbut, agama dalam masyarakat Kaloran dimaknai sebagai ageman (pakaian) yang memakainya sesuai dengan kecocokan individu. Atas dasar keyakinan pada kesadaran kita diciptakan memang berbeda dengan mempunyai pakaian sesuai dengan kecocokannya, maka ralasi antar umat beragama yang memiliki tradisi dan tata cara yang berbeda tidak menjadi permasalahan yang substansial. Terbangunnya konstruksi kesadaran tersebut, juga dikonstruksi atas dasar manusia tidak mampu hidup sendiri tanpa adanya perbedaan dari orang lain.

\section{b. Bahasa sebagai Instrumen Dialog dengan Hati}

Relasi keagamaan tidak akan terjadi tanpa adanya instrument dalam dialog antar umat beragama. Instrument dialog ini sering menggunakan bahasa sebagai media komunikasi dalam bermasyarakat dan berkehidupan keagamaan di masyarakat Kaloran. Bahasa ini menjadi literasi masyarakat baik secara lisan maupun tertulis dalam memaknai, menjelaskan, dan merespon fenomena yang terjadi di masyarakat. Literasi sering dijelaskan sebagai bagian dari produk interaksi antara jasmani dan 
pikiran $^{5}$. Dalam merespon fenomena yang ada di Masyarakat Kaloran sering merelasikan dengan adanya literasi konsep Tuhan.

Bahasa yang menjadi litersi masyarakat Kaloran dalam menyebutkan konsep Tuhan dengan berbagai nama dan penjelasan. Perbedaan konsepsi bahasa tentang Tuhan tersebut tidak menjadikan substansi permasalahan dalam dialog antar umat beragama. Bahasa yang sering digunakan dalam komunikasi mengenai kosep Tuhan oleh umat Islam dan Kristen justru sering menggunakan Gusti Allah. Dengan relasinya bahwa Tuhan tersebut sering disebut Allah. Begitu juga dengan bahasa Tuhan dalam komunitas Buddha lebih sering menggunakan litersi Gusti Pangeran karena Buddha Gautama sebagai guru umat Buddha berasal dari Pangeran dari kerajaan Kapilavastu di Magadha. Sehingga dalam mengejawantahkan litersi konsep Tuhan dalam masyarakat Kaloran menggunakan kata yang lebih sesuai yaitu Gusti Pangeran. Sebutan Gusti Pangeran ini juga terjadi di masyarakat Klaten sewaktu merespon atas bencana gempa bumi khususnya pada komunitas Buddhis di Klaten ${ }^{6}$. Dari perbedaan penggunaan bahasa tersebut tidak menjadi masalah, dalam relasinya dialog litas agama. Kesadaran atas perbedaan penggunaan bahasa tentang Tuhan ini tidak mengurangi makna berdialog antar umat Buddha.

Tidak hanya perbedaan konsep Tuhan dengan berbagai bahasa yang digunakan masyarakat Kaloran dalam berdialog, tetapi dengan ditunjukkan aksi sosial dengan kesadaran hatinya sebagai makhluk beragama. Aksi sosial ini sebagai bentuk keselarasan antara jasmani dan pikiran dalam mengimplementasikan diri dalam dialog lintas agama. Tidak ada bangunan tempat ibadah yang berdiri tanpa adanya setuhan dan uluran tangan atau tenaga dari unsure lintas agama. Kegiatan ini yang menjadi ruang dialog antar umat beragama dengan hati. Prisip kegotongroyongan ini menjadi sumber bahasa hidup dalam komunitas beragama. Tidak hanya pembanguan tempat ibadah saja, sampai dengan rumah penduduk, tempat umum seperti pos ronda, jembatan, selokan, dan kuburanpun tidak terlepas dari relasi dan kontribusi dari masyarakat lintas agama. Bahasa sebagai instrumen dialog ini dapat dimanifestasikan baik dalam bentuk komunikasi maupun aksi dalam masyarakat lintas agama di Kaloran, Temanggung.

\footnotetext{
${ }^{5}$ Materi kuliah Kitab Keagamaan dan Masyarakat oleh Yusak B. Setyawan Ph. D. yang dijelaskan pada hari Selasa, 23 Oktober 2018.

${ }^{6}$ Suranto. 2010. Thesis: Buddhisme Theravada dan Gempa Bumi: Respon Umat Buddha terhadap Gempa Bumi 27 Mei 2006 (Studi Kasus di Dusun Gatak, Kotesan, Prambanan, Klaten). Yogyakarta: CRCS, UGM.
} 


\section{c. Kearifan Lokal (Budaya) sebagai Ruang Publik Masyarakat}

Budaya dalam komunitas masyarakat Kaloran menjadi media dan sarana masyarakat sebagai ruang publik mereka dalam relasinya dengan masyarakat lintas agama. Salah satu budaya lokal yang dilakukan oleh masyarakat Kaloran adalah Sadranan. Sadranan ini merupakan tradisi selamatan yang dilakukan oleh masyarakat Kaloran yang diselenggarakan di Kuburan pada umumnya. Tadisi Selamatan ini sebagai wujud dari rasa syukur terhadap Tuhan, para leluhur, dan alam semesta atas berkah yang sudah ada dalam masyarakat tersebut. Meskipun demikian, dalam ranah kearifan lokal tersbut tidak terlepas dari kesadaran bersama atas perbedaan agama yang ditujukkan dengan berbagai aktifitas seperti doa bersama lintas agama, berbagai makanan, kumpul keluarga, dan juga dialog. Dalam proses ini ruang publik mayarakat tercipta dalam kearifan lokal budaya Sadranan.

Selain sadranan, kesenian menjadi media dialog pada ruang publik masyarakat Kaloran. Kesenian yang menjadi bagian dari budaya tersebut menjadi media yang cukup diterima dengan baik oleh masyarakat Kaloran. Kondisi ini tampak dari aktifitas kesenian yang semakin berkembang di lingkungan multi agama tersebut. Sebagai realitas tersebut, dalam kesenian kuda lumping, topeng ireng, ketoprak, wayang kulit, dan sorengan tidak terlepas dari anggota berkesenian tersebut lintas agama yang kemudian menghasilkan karya bersama tanpa harus mengedepankan identitas keagamaannya. Sebagai contoh dalam seni kuda lumping atau kuda kepang yang menjadi pemeran atau artisnya dapat terdiri dari komunitas Muslim, Kristen, dan juga Buddhis. Peran-peran ini tampak dari hasil karya dalam bidang seni yang dipadupadankan dengan habitus keagamaan. Misalnya saja umat Kristen memiliki kemampuan dalam bidang alat musik menjadi penabuh instrumen, uamt Buddha dan Islam menjadi penarinya. Berbagi peran dalam berkarya di bidang seni tersbut sebagai manifestasi dialog di ruang publik dan juga menjadi bukti dialog lintas agama dengan sepenuh hati atas dasar memanusiakan manusia.

\section{Dualisme Identitas dalam Nasionalisme Pancasila}

Secara sosio kultural bangsa Indonesia masyarakatnya mempunyai dualisme identitas dimata nasionalisme pancasila. Indonesia adalah sebiah realitas dengan dua 
identitas ${ }^{7}$. Indentitas primordial ini merupakan identitas yang sudah ada sejak mereka hadir di bumi ini yang tidak terlepas dari ikatan identitas budaya, agama, ras, maupun etnik yang sudah mengikatnya. Berdasarkan variasinya identitas primordial ini sebagai wujud dari pluralisme sebagai realitas masyarakat Indonesia. Meskipun demikian, dalam identitas primordial tersebut mempunyai identitas nasional Indonesia sebagai identitas baru yang menyatukan semua masyarakat yaitu identitas bangsa Indonesia. Kekosongan dari identitas bangsa Indonesia ini membuat bangsa Indonesia sampai sekarang sedang berjuang dalam memposisikan masyarakat pada titik kesatuan bangsa Indonesia ${ }^{8}$. Tantangan ini muncul berdasarkan pada kompleksitas idiologi pada bangsa ini yang tidak terlepas dari tiga idiologi besar yang relasinya untuk mengisi gap tersebut yaitu nasionalisme, Islam, dan Marxisme ${ }^{9}$. Tantangan ini sebenarnya muncul pada belakangan ini atas reaksi dan aksi dari kelompok tertentu yang kemudian berkembang sampai saat ini. Pada masa awal kemerdekaan ini, dengan identitas nasional telah menjadi senjata yang ampuh dalam menyatukan masyarakat bangsa Indonesia. Tantangan yang kuat terjadi pada para pemimpin bangsa ini dalam menjaga peradaban melalui konsep nasionalisme ini, yang kadang sering diingkari. Seperti yang diampaikan John Titaley bahwa "setelah melalui beberapa tahap dalam sejarah Indonesia, model toleransi keberagamaan pancasila ini diabaikan; para pemimpin negeri ini seakan mengabaikan maksud mulia dari peara pendiri bangsa; konsekuensinya berbagai macam deskriminasi agama terjadi di negeri ini"10. Meskipun dalam sejarah bangsa ini, nasionalisme akan semakin kuat ketika agama juga semakin kuat dalam mengisi kemerdekaan ini. Tidak pernah bangsa ini dimenangkan oleh partai berbasis agama. Ini sebagai bukti kekuatan ideology bangsa atas kesadaran bersama dalam keberagaman. Hal ini terjadi karena sebagian sosiolog justru berpandangan bahwa kemunculan nasionalisme berakar bukan pada saat kemunduran agama namun justru pada saat agama menguat, disitulah muncul dan berkembangnya nasionalisme (Turner, 2013: 1062)

\section{Kesimpulan}

\footnotetext{
7 John A. Titaley. 2013. Religiositas Alinea Tiga: Pluralisme, Nasionalisme, dan Transformasi Agamaagama. Salatiga: Satya Wacana University Press. Halaman. 157

8 Ibid. halaman. 158

${ }^{9}$ Sukarno. 1963. Nasionalisme, Islamisme, dan Marxisme. Dalam catatan Sukarno Di Bawah Bendera Revolusi Djilid I. Djakarta: Panitiya Penerbit dibawah Bendera Revolusi.

10 John A. Titaley. 2013. Religiositas Alinea Tiga: Pluralisme, Nasionalisme, dan Transformasi Agamaagama. Salatiga: Satya Wacana University Press. Halaman. 155
} 
Manifestasi kearifan lokal sebagai akar nasionalisme pancasila menjadi penting dalam peranannya untuk membaca konstruksi sosial masayarakat dalam relasinya dialog antar umat beragama di Kaloran, Temanggung. Berdasarkan petanyaan bagaimana kearifan lokal sebagai akar nasionalisme Pancasila pada dialog lintas agama ini, dapat terjawab atas manifestasi dari kearifan lokal ini seiring selangkah dalam menjaga kerukunan umat beragama melalui mitologi, bahasa, dan budaya sebagai point penting untuk kehidupan beragama di Kaloran.

Konstruksi elemen masyarakat dalam mewujudkan kerukunan umat beragama, secara sosiologi dan alami dari masyarakat itu sendiri menjadi kekuatan yang paling penting. Konstruksi kerukunan baik dalam usaha menjagannya atau mewujudkannya lebih mengena jika konstruksi tersebut lahir atas dasar kesepakatan dari masyarakat itu sendiri, karena kesadaran tersebut lebih alami dan terkonstruksi dengan baik dalam hati masyarakat.

Melalui mitos yang dibangun dalam masyarakat, kesadaran konsep Tuhan dengan perbedaan bahasa, dan budaya lokal tersebut menjadi akar dalam membangun komunikasi dan aksi dalam mewujudkan keharmonian kerukunan umat beragama di Kaloran. Kondisi ini yang menjadi immune masyarakat dalam menghadapi realitas keberagamaan di Kaloran yang justru menjadi kekuatan dan kekayaan masyarakat atas perbedaan agama.

Meskipun pada akhir-akhir ini tantangan nasionalisme lebih berat dalam menghadapi krisis identitas dari masyarakat bangsa Indonesia itu sendiri. Kita tidak berhadapan lagi dengan penjajah secara fisik, melainkan justru sedang manghadapi kisis identitas dari masyarakat bangsa kita sendiri. Sehingga tidak aneh jika diberbagai tempat berkembang kelompok tertentu yang mencoba mengguncang ideology bangsa ini. Menjadi refleksi bersama, kegaduhan idiologi muncul karena adanya pertarungan politik saja atau memang sudah saatnya pemerintah harus tegas dalam menjaga kedaulatan NKRI dan Pancasila sebagai idiologi tunggal bangsa ini. Yang perlu dipertimbangkan, tidak selayaknya bangsa ini hancur karena ulah dari warga bangsanya sendiri. Sejarah telah mencatat bahwa penjajahan telah menyatukan kita.

\section{Daftar Referensi}

Al Qurtuby, Sumanto. 2016. Religious Violence and Conciliation in Indonesia: Christians and Muslim in Moluccas. New York: Roudladge. 
Asmtrong, Karen. 2015. Fields of Blood: Religion and the History of Violence. London: Vintage.

Hick, John. 1980. God Has Many Names. London: Palgrave Macmillan.

John A. Titaley. 2013. Religiositas Alinea Tiga: Pluralisme, Nasionalisme, dan Transformasi Agama-agama. Salatiga: Satya Wacana University Press.

Lattu, Izak. Culture and Christian-Muslim Dialogue in Moluccas-Indonesia, Interrelegious Insight: A Journal of Dialogue and Engagement 10, no. 1 (July 2012): 45-52.

. 2018. Beyond Interreligious Dialogues: Orality Based Interreligious Engagements in The World Biggest Muslim Majority Country, Indonesia.

Madjid, Nurcholis. 1999. Cedikiawan dan Religiusitas Masyarakat. Jakarta: Paramadina Press.

McFague, Sallie. 1982. Metaphorical Theology: Models of God in Religious Language. Philadelphia: Fortress Press.

Siddiqui, Attaulah. Christia-Muslim Dialogue in the Twentieth Century. London: Macmillan Press.

Suhadi. 2014. I Come from a Pancasila Family: A Discursive Study of Muslim-Christian Identity Transformastion in Indonesia post Reformation era. Berlin: Lit Verlag.

Suranto. 2010. Thesis: Buddhisme Theravada dan Gempa Bumi: Respon Umat Buddha terhadap Gempa Bumi 27 Mei 2006 (Studi Kasus di Dusun Gatak, Kotesan, Prambanan, Klaten). Yogyakarta: CRCS, UGM.

Swidler, Leonard. The History of Interreligious Dialogue: In Catherine Cornelle (Ed.). The Wiley-Blackwell Companion to Interreligious Dialogue. Oxford and Malden: Wiley Blackwell.

Turner, Bryan S (Ed.). 2010. The New Blackwell Companion to the Sosiology of Religion. Terjemahkan oleh Daryatno. 2013. Sosiologi Agama. Yogyakarta: Pustaka Pelajar.

Turner, Jonathan H. 1998. The Structure of Sociology Theory. USA: Wadsworth Publishing Company. 
